\title{
ЛИСТИ ТА ВІРШІ В. СТУСА ЯК МАТЕРІЯ ТА ДУХ ЙОГО ІСТОРІЇ КОХАННЯ
}

Статтю присвячено розгляду інтимної лірики В.Стуса в контексті його листування з рідними. Осмислюється значення коханої жінки в практиці духовного перетворення поета та смислові конщепти Стусового міфомислення, пов'язані з інтимними інтенціями. Досліджено також значення снів, видінь та спогадів для виокремлення головних сюжетів психобіографії поета.

Ключові слова: філософський мазохізм, психотип мужності, орфізм, потойбіччя, енергія єднання / роз'єднання, Ерос, Танатос, свідома любов.

Статья посвящена рассмотрению интимной лирики В.Стуса в контексте его переписки с близкими. Осмысливается значение любимой женщины в практике духовного пересотворения поета и смысловые концепты мифомылиления В.Стуса, связанные с интимными интенциями. Исследовано также значение снов, видений и воспоминаний для выделения главных сюжетов психобиографии поета.

Ключевье слова: философский мазохизм, психотип мужественности, орфизм, потусторонний мир, энергия соединения / разъединения, Эрос, Танатос, сознательная любовь.

The article focuses on the intimate poems by Vasyl Stus in the context of this correspondence with loved ones. The comprehension of the loved woman value in the spiritual transformation of the poetical practices and semantic concepts of Stus' unusual interpretation of the myths related with intimate intensiyamy. The influence of the 
dreams, visions and reminiscences on the determining the main periods of the psychological biography of the poet is studied as well.

Key words: philosophical masochism, the psychological type of courage, orphism, the other world, the energy of connection/ disconnection, Eros, Qanatos, conscious love.

Проблеми майстерності творення В.Стусом інтимної лірики торкались малочисельні дослідники творчості поета, розуміючи, очевидно, велику міру відповідальності та складність такого завдання.

Розкриваючи духовний образ адресатки в любовній ліриці поетів - дисидентів, Г. Райбедюк зазначає, що «дослідження широкого спектру інтимних рефлексій дисидентів може стати одним із оптимальних шляхів декодування їхньої лірики, естетичного сенсу літературного дисидентства загалом». Визначальним в любовних віршах в'язнів сумління дослідниці видається те, що «складні людські взаємини ієрархізуються майже до містичного екстазу злиття індивіда 3 духовним началом буття» [Райбедюк 2013: 372].

І.Дзюба вважає, що якби талант Стуса розвивався за нормальних умов, то все одно «основні мотиви були б ті ж, $і$ отой же трагізм його» [Дзюба 2003: 265]. І.Дзюба виділяє два головні мотиви Стусової поезії: «весь обшир душевних страждань $i$ оче пережсивання долі рідних, долі сина, дружини, матері ... Це, по моєму, найстрашніше в його поезії. Я не знаю, чи в когось ще $\epsilon$ таке. Це те... щуо людина в тюрмі не за себе мучиться, а за отих найближчих людей, які опинилися без неї, яких вона мимоволі нещзасними зробила не з своєї вини» [Дзюба 2003: 256].

На думку Л.Плюща, В.Стус в «Палімпсестах» створив український образ фавстівської Маргарити, безневинної жертовної душі, що втілює вищу мудрість, є Софією. Ця жіноча душа болем своїм відбілює бруд реальності «до святости, до білоти - символу безсмертної людської душі» [ Плющ 1987:229].

Прагнучи до певного синтезу у з'ясуванні основ філософсько-естетичної системи В.Стуса, дослідники все ж фрагментарно й мимохідь торкалися аналізу інтимної лірики поета. Продуктивного 
методу іiі відчитання як концептуальної теми творчості митця ще не вироблено.

У Стусовій філософсько-естетичній системі любов посідає одне 3 чільних місць. Вона одночасно і земна горизонталь, і духовна вертикаль, матерія і дух.

Д. Стус зазначає, що у своїй творчості В.Стус «прагнув з перемінним успіхом здолати вічну роздвоєність між духом та плоттю» [Стус Д. 2001: 33]. Відчитуючи вірші В.Стуса як відкриту книгу його біографії, дослідник задається питанням, «як же иุе викласти в самій канві біографічного тексту Василя Стуса?». I пропонує за головний принцип організації та подачі матеріалу «максимальну співдію двох основних складових спрямованої у минуле машини часу - літератури та реальної історії - ідеї та життя - духу та матерії» [Стус Д. 2001: 33].

В контексті біографії ув'язненого В.Стуса саме тексти залишаються лініями його живого буття. Та ще листи - найцікавіше 3 документалістики митця.

Н.Зборовська у своїх психоаналітичних дослідженнях твердить, що «психобіографія $і$ творчість В.Стуса яскраво відображали позицію філософського мазохіста, який ідентифікував свій илях з мужньою дорогою болю як зі шляхом сина Божого $і$ сина національного, натхненного потойбічною волею Бога-Отия» [Зборовська 2006: 352].

Розглядаючи мазохізм як первинну психічну реальність, пов'язану з Танатосом, потягом до смерті і одночасно з потягом до життя за умови набування ерогенності, дослідниця спирається на характеристику психології філософа, зроблену Платоном на основі потягу до смерті як потягу в трансцендентне, що формується за межами сексуального інстинкту: «філософ прагне дійти до чистого пізнання, яке можливе лише за умови звільнення від впливу тіла, тому філософи справді прагнуть померти, тобто очиститися, визволитися від нерозважливого впливу тіла і пізнати чистоту, якою є трансцендентна істина» [Зборовська 2006: 80]. 
На думку дослідниці, психотип українського філософа вивершив у «старосвітській» літературі Г.Сковорода, згодом - у поезії Т. Шевченко, в сучасній літературі - В.Стус.

Обираючи психоаналіз одним з методологічних ключів до творчості В.Стуса, ставимо завдання з'ясувати, як в інтимній ліриці поета відобразилась позиція філософського мазохіста як співвідношення енергії Танатосу й Еросу і репрезентувався через реалізацію коду батьківства мужній український психотип, а також, в якій мірі інтимна лірика поета втілює ключові сюжети його психобіографії.

Спробуємо також у процесі аналізу віршів В.Стуса 3'ясувати роль кохання у перетворенні енергії розщеплення (Танатос) в енергію єднання (Ерос - Любов), що загалом допоможе в осмисленні універсальності світогляду митця.

Оскільки універсальність філософського світогляду В.Стуса зумовила синтетичність його художнього стилю, то наступне завдання полягає у можливому виявленні мовних маркерів любові, а також любовної символіки у віршах поета періоду ув'язнення.

Починаючи з середини 60-х - початку 70-х років, В.Стус в нестерпних умовах шукав шляхи реалізації своєї поетичної суті, що вже тоді була його абсолютною істиною. Він мав громадянську мужність захищати права репресованих молодих українських поетів, став на позицію послідовного бунту аж до прийняття можливої суспільної ізоляції. На думку Н.Зборовської, тільки так національний суб'єкт міг тоді реально впливати на ситуацію в суспільстві [Зборовська 2006: 352].

Паралельно цим подіям розвивалась лінія особистого життя поета. Кохання стає другою його абсолютною цінністю. В.Стус одружився з Валентиною Попелюх 1966 року. Це був, за словами свідків, «не святковий шлюб» [Коцюбинська 2003: 60], бо молодий не міг вповні насолоджуватись своїм особистим щастям, знаючи, що його друзі в ув'язненні. За спостереженнями Н.Зборовської, у мужнього національного суб'єкта в умовах колоніальної націона- 
льної несвідомості закономірно відсутній інфантильний принцип насолоди, який загрожує самоспустошенням [Зборовська 2006: 352]. У свій весільний день В.Стус просив пробачення в Надії Світличної за іï ув'язненого брата Івана, наголошуючи, що сам він лише випадково лишається на волі. Доля видала тоді кредит на 6 років спільного подружнього життя і вже у 1972 році, за словами дружини, «забрали до кінця життя» [Попелюх 2003: 35] .

Вже перші вірші зі збірки «Час творчості» відбивають моторошне протистояння дня і ночі ув'язненого поета. Вдень він перебуває під владою Танатоса, його змагає відчуття порожнечі. Лише вночі кохання існує як “нічне сніння", як самонавіювання образу коханої, як спогад, як несамовите чоловіче бажання бути разом, як нетривка упевненість у можливому щасті:

щзо там десь є син і там є ти, моя голубко вижурена, люба, ти за межею, за ріллею, там,

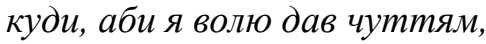
на ліктях зміг би доповзти...

(«Здається, кожен день до мене йдуть листи...»)

[ Стус В.1995: 16].

Вся інтимна лірика В.Стуса періоду ув'язнення відповідає жанру видінь, про природу якого він писав у листі до дружини від 03.01. 1974 року: «Ось коли мені не спиться, я часто наслухаю Васмоїх найрідніших: маму, Тебе, Дмитра, Михасю. I в такі хвилини викликання далеких образів я помічаю щуось таке, чого не можна було помітити зблизька, а тільки - з-за відстані, $і$ то - безмежної» [Стус В.1997: 63]. В процесі аналізу віршів переконуємося, що сни й видіння як вираження підсвідомих бажань поета, відбивають ключові сюжети його психобіографії.

Фатальною перепоною до об’єднання з родиною постає у віршах - видіннях образ містичної межі, що відділяє від коханої як символу життя і щастя, ніби поділяє світ навпіл. Своє ув'язнене 
буття поет пов'язує з пекельним потойбіччям, де діють жорстокі, нелюдські умови.

3 листів бачимо, яку лють і водночас безсилля пережив В.Стус, коли табірна влада, дозволивши взимку 1973 року побачення 3 дружиною, заборонила його вже по приїзді Валентини Попелюх у табір. 3 листа від 15.02 1973p., написаного до дружини й сина зразу після цієї драматичної пригоди, бачимо, як жорстока реальність примушувала Стуса обирати позицію філософського мазохізму, що була єдино можливою і єдино правильною в тих умовах: «Ти, Валю, не май на мене гніву - підводжу Тебе не я, а мої умови, у яких я набуваю страшного понадолімпійського спокою». I далі: «Бо єдине, за що тут можна вхопитися, - це за скупе читання після роботи, аби погамувати гнів на дику сваволю недоуків логінових та мезер» [Стус В.1997: 16] .

Н.Зборовська доходить висновку, що «украӥнський мужній мазохізм виявляе перевагу любові над сексуальністю» [Зборовська 2006 : 80], посилаючись на життя і творчість Г.Сковороди й Т. Шевченка, на їхню релігійність, яка віддзеркалювала «мазохістську психологію Христа, що передбачає принесення тілесності (несвідомого) у жертву божественному світові заради вищої свідомості» [Зборовська $2006: 80]$.

У випадку Стуса його відмова від тілесності не була добровільною. Вірші «Часу творчості» випромінюють еротичні бажання- спогади й велику силу волі для їхнього подолання в умовах неволі, що для чоловіка, який знав щастя взаємного кохання, рівнозначно смерті:

Тихо ми входили в досвіток шарий, не спамятавщись од віщої ночі.

Куталась ти у лисичий свій комір, кутався я у дитинячий стид.

Ніч приховала гріхи намі периі, ти вибачала мене, вибачала, ти прилучала мене, прилучала 
до таємниці розкошів - смертей.

Краще померти, бо,мабуть, нічого

Більше не буде...

(«Пахло весною і прілою глицею») [Стус В. 1995: 189].

Чимало віршів зі збірки «Час творчості» можна назвати справжніми зразками еротичної лірики: «Десь пише сонце фантастичні кола» [Стус В.1995: 66], «На незабудь - дружині» [Стус В.1995: 129], «Коли ти за шеломянем...» [Стус В.1995: 157]. Поет «на віддалі голодної жаги» перебуває в полоні «отих очей, отих монгольськи - зляканих, / сливових, довгуватих, як мигдаль», в полоні «студентських молодечих днів», «де вперие знагла / збагнув я те, чого не зрозуміть / мені й подосі» («Коли ти за шеломянем, коли ти...») [Стус В.1995: 157]. Одначе в цих віршах кохання i біль органічно поєднані, чоловіча пристрасть і бажання поєднані 3 воланнями розіп'ятого, «із зашпорами серця» [Стус В. 1995: 157]. Можливо, в Стусовій «естетиці страждання» саме ці вірші є головним емоційним центром.

Не можна стверджувати, що інтимна лірика В. Стуса позбавлена відчуттів насолоди. Про це свідчать запахи та кольори, що маркують іiі. Син асоціюється 3 кольором, що несе енергетику тепла - жовтогарячим. Метафора «ручки розкрилив жовтогарячі» [Стус В. 1995: 54] переходить від дружини на сина, образ якого був для поета другим невичерпним джерелом тепла, життєдайності, точкою опори на зірваній орбіті. Дружина - білий колір, як святість і як біль: «а біля мене білим соболем / тремтить коханої рукав» [Стус В. 1995: 158]. Обох коханих об'єднує п'янкий бузковий запах: «Рясним букетом білого бузку, / зарошеним у радість, син наснився» [Стус В.1995: 126]; «А ти, як гілочка бузку, наснилася мені» [Стус В. 1995: 127].

Лише керуючись здоровим глуздом, аби не збожеволіти, уникнути тяжкого неврозу, зрештою, повернутись до Неї бодай психічно здоровим, поет займає позицію філософа, увесь час впродовж подальших років ув'язнення намагаючись розірвати 
містичне коло потойбіччя й за посередництва трансцендентних сил наблизитися до Неї, до Бога, що означало для нього одне й теж. Так відбувалася міфологізація образу коханої, в якому поєднувалися риси реальної земної жінки з ідеалізованою фігурою, що виразило вищу духовну потребу чоловіка в милосерді, порятункові від душевного холоду й самотності, сприяло відновленню забутих релігійних почуттів.

На день народження дружини 1973 року ув'язнений поет створив вірш $з$ фрагментів текстів свого улюбленого Р.М. Рільке. У вірші передано не лише глибину почуття, а й його перетворення під впливом фатальних трансцендентних сил: «Я люблю так глибоко, так високо, так / неосяжно, / як (наскільки) моя душа сліпо багата, коли вона / своє буття відчуває і вічність. /...І якщо є Бог, / хочу тебе більше любити після смерті» (Лист до батьків і сестри від 10.06. 1973 р.) [ Стус В. 1997: 33- 34]. Вірш проймає рількеанська інтуїція, коли в теперішньому своєму бутті душа прочуває вічність. Танатос як енергія роз'єднання 3 коханою перетворює кохання земного чоловіка в любов - вищу і вічну духовну субстанцію, що переборює смерть і об'єднує у вічності. Любов, на відміну від кохання, формується як істинне знання про чистоту, як одна 3 християнських чеснот за межами сексуального інстинкту. Про таку любов поет говорив лише у разі своєї смерті

В інтимній ліриці В.Стуса розлука виявляється як Танатос потяг до смерті, супроводжуваний страхом невідворотної утрати, страхом за осиротілу любов і родину:

Мов на антоновім огні, не чув нічого я й не бачив, в останньому зусиллі зміг збагнути: все. Тебе я втрачу, от тільки заверну за ріг.

(«Мов лебединя, розкрилила...») [Стус В. 1995: 22].

Енергія роз'єднання змагає і буття коханої. Стусова інтимна лірика упізнається через головний символ любові, в який він вкла- 
дає своє захоплення трагічною красою, чистотою й вірністю коханої це образ лебедині, що у відчаї втрати своєї пари «розкрилила тонкоголосі дві руки» [Стус В. 1995: 22]. «Тонкоголосий»- теж суто стусівський мовний маркер, трагічна звукова аура голосінь, що виповнює в'язничний простір поета і розростається до вселенських меж.

Руки коханої, улюблений метонімічний образ поета, що є втіленням жіночої чуттєвості, ніжності й тепла, на довгій розлуці висамітніли. Невимовних страждань зазнає поет, розуміючи, що його відсутність зробила дружину беззахисною й вразливою. У видіннях рука дружини маркується епітетами «беззахисна, самотня і тонка» («Чи витримаєш ти найтяжчий іспит...») [Стус В. 1995 : 22].

Водночас саме ця тонка звукова аура голосінь на рівні чуття об’єднує поета з коханою, що лишилася «із велетенською, як світ, бідою» [Стус В. 1995: 22]. Об’єднує так, як спільні страждання, «прекрасна катастрофа»,якої вони зазнали, уміння витримувати «біду вселюдську», що вивищує їх як обраних для високої долі й справжнього життя. Свої міркування Стус втілював в поетичні афоризми, адресовані дружині й покликані розрадити іiі, переконати в правильності обраного шляху: «Ти страждала? Отже, ти жила» («Вимріяна і жива донині...») [Стус В. 1995: 23].

Інтимні інтенції поета пов'язані з орнітоморфними образами символами утраченого родинного гнізда, що асоціюється з теплом, репрезентує світ «жовтогарячий і мосянжний». Слово мосяж рідковживане і означає те саме, що латунь - жовта мідь. У Стусовому поетичному світі завжди маркує простір рідної землі або інтимний простір і є синонімом теплих кольорів, підсилюючи їх. У вірші «Вертають журавлі на ветхі гнізда» [Стус В. 1995: 91-92] поетові бачиться щаслива пара журавлів, в якій журавлик став журавлисі «за сина, друга і дружину». Ї̈ ж він так само допильновує й годує, «немов дитину, матір і дружину». Обидва перебувають на вірі, що їх рід продовжиться, «щзо од срібного шнурочка / урветься чиста ясногорла тронка, / $і$ закружляє молода журавочка / понад давно занедбаним гніздом». Картини родинного гнізда 
викликані найболючішими спогадами поета, що ніби повільна «смерть уроздріб». Йому судилося не - повернення в своє гніздо, $\mathrm{i}$ усвідомлення на хисткій «кладці віку», що щастя «усе в минулому». Вірш відбиває той драматичний час утрат у психобіографії поета, коли він не зі своєї волі почав проходити кола відчуження від земного життя і вже підходив до тієї межі, що вела його у світ духовних ініціацій, даруючи можливість подолати власну смерть. Крім того, й спогади про інтимний простір свого буття поет сприймав із вдячністю долі, як подовження життя, як можливість «стати позаду смерті власної».

Вибір Стуса, під час якого він відмовляється від затишного родинного життя, жертвує всіма земними насолодами, збувається тілесності, зберігаючи неушкодженою свою поетичну суть і вивершуючи себе духовно, свідчить про те, що його життя виражало мужній національний психотип.

Листи В.Стуса до дружини є його трагічною кардіограмою втрати свого тіла: спочатку втрачав зуби, міняв їх на сталеві коронки (лист від 09.1973року), [Стус В. 1997: 45], відтак збувся однієї третини шлунку (лист від 10.08.1975 року), [Стус В. 1997: 158], втратив 10 кг ваги, мав 62 кг (лист від03.01. 1976 року) [Стус В. 1997: 208] , але, попри все, найдужче хвилювався за той орган, що 3 його сюрреалістичного погляду відповідав за вірші: «Я боюся, чи не зачепив хірург чогось того, що писало вірші раніше, але, здається, не зачепив» (лист від 08.03. 1976 року), [Стус В. 1997: 220].

Український поет, як і Данте - вигнанець, вважав за неможливе принижуватись перед своїми політичними опонентами i психологічно почувався «не переможеним, а переможцем...» (лист від 28. 07. 1974 року), [Стус В. 1997: 89]. В.Стус був вдячний дружині за розуміння, у листах постійно писав їй про свій вибір «за принципом гідності, за критерієм честі» [Стус В. 1997: 132]: «Жити у становищі заџькованого зайченяти, якому загрожує кожне шолудиве собача, - то роль не для мене. Як не для мене роль - писати опуси в дусі Зені. Зневажати себе, втрати- 
вии почуття власної гідності, я не годен» ( лист від 26. 02. 1975 року), [ Стус В. 1997: 129].

Стус мислив, що його кохання не сумісне 3 хворостями. Не хотів писати дружині, які вживає ліки, «бо мої почуття до Тебе не терплять такого сусідування - бубки, хворості і подібна проза» (Лист до дружини від 22.11. 1978 року), [Стус В. 1997: 329]. Мистецтво ж - не сумісне з тілом. Воно - вічність. Перебуваючи під впливом Рільке, «Сонети до Орфея» якого перекладав з 1973 року, Стус втілив у своїх в'язничних віршах чимало орфічних ідей. Він, як і його геніальний вчитель, розглядав мистецтво не лише як феномен індивідуального духовного перетворення, а й світового, що допомагає приборкувати жорстокість, агресію та абсурд - звірів людського буття, які в потойбічному світі підкорились лише музиці Орфея. Мистецтво було для Стуса всім, втіхою, більшою за кохання: «Мабуть, на цуьому світі тільки й радості - підставити свої руки під золотий потік натхнення - $і$ пригубити води. Бо більшої втіхи немає» (Лист до дружини від 13. 06. 1976 року), [Стус В. 1997: 226]. За можливість творчої реалізації, або інакше - за духовну свободу, він пожертвував своєю тілесною свободою, коханням, просив дружину про розуміння, вибачався за свій безпровинний гріх перед Нею.

Про драматичну розлуку 3 коханою, про неможливість об’єднання в земному житті, про мистецтво як орфізм, що допомагає осягнути буття й небуття, скеровує шлях поета у вічність йде мова у вірші «Усе життя моє прожите...»:

Віки - попереду у тебе,

В століття свій скеровуй лет.

Єси поет, запраглий неба, Во віки і віки-поет! [Стус В. 1995: 58].

У цьому вірші автор постає у своїй найсуттєвішій міфічній іпостасі - як поет, співець, що має надзвичайну владу над усім.

Такі вірші як «Спить жона, золотими ножами...», «Десь пише сонце фантастичні кола» свідчать, що В.Стус також розглядав 
смерть як надію на визволення від болю, на своє духовне воскресіння в творчості й надію на вічне повернення до Неї.

Отже, дискурс кохання у в'язничній ліриці В.Стуса виступає як енергія роз'єднання, яка в процесі духовного пересотворення себе самого перетворюється в енергію єднання з коханою. Інтимна лірика відбиває такі ключові сюжети психобіографії митця: вимушена розлука - трагічне відчуження від земного життя - обрання позиції філософського мазохізму - самособоюнаповнення як реалізація у творчості - перехід межі з території профанного в сакральний простір, що передбачало досягнення безсмертя духовного через тілесну смерть та подальше об'єднання з божественним і 3 Нею. Можна виділити такі Стусові мовні маркери любові, що роблять упізнаваною його поезію загалом: голодна жага, зашпори серчя, тонкоголосий, висамітнілі руки, вись / паділ, час утрат / час набутків. Любовна символіка пов'язана 3 орнітоморфними образами лебедині та утраченого родинного гнізда, які розкривають глибину переживання трагічного в житті поета. Кольорова семантика та семантика запаху передають насолоду, знеболення від спогадувань коханих образів дружини та сина. Ключові сюжети психобіографії, виявлені в інтимній ліриці В.Стуса, мовні маркери любові та любовна символіка підтверджують універсальність мислення поета, його розуміння антитетичної природи буття, що виявилось і в інших темах його творчості.

\section{БІБЛІОГРАФІЯ}

Дзюба 2003 - Дзюба І. Нецензурний Стус. Книга у 2- х частинах. Ч.2[ Упоряд. Богдана Підгірного] / І.Дзюба. - Тернопіль : Підручники і посібники, 2003. C. $222-262$.

Зборовська 2006 - Зборовська Н. Код української літератури: Проект психоісторії новітньої української літератури. Монографія / Н.Зборовська. - К.: Академвидав, 2006. -504 c.

Коцюбинська 2003 - Коцюбинська М. Нецензурний Стус. Книга у 2- х частинах.

Ч.2[ Упоряд. Богдана Підгірного] / М. Коцюбинська. - Тернопіль: Підручники і посібники, 2003. - С.52- 80.

Плющ 1987 - Плющ Л. Вбивство поета // Василь Стус в житті, творчості, спогадах та оцінках сучасників[ Упоряд. Осипа Зінкевича] / Л.Плющ. - Балтимор Торонто: Вид - во «Смолоскип» ім. В.Симоненка, 1987. - 463 с. 
Попелюх 2003 - Попелюх В. Нецензурний Стус. Книга у 2- х частинах. Ч.2[ Упоряд. Богдана Підгірного] / В. Попелюх. - Тернопіль: Підручники і посібники, 2003. - C.28-51.

Райбедюк 2013 - Райбедюк Г. Духовний образ адресатки в любовній ліриці поетів дисидентів // Актуальні проблеми словянської філології. Серія: лінгвістика і літературознавство : міжвуз. зб. наук. ст..;(гол. ред.. В.А.Зарва). - Бердянськ: БДПУ, 2013. - Вип. ХХУІІ. - Ч.4. - С.371-382.

Стус 1995 - Стус В. Твори / В.Стус // Твори: У 4 т., 6 кн. - Львів: Просвіта, 1995. T.2. $-429 \mathrm{c}$.

Стус 1997 - Стус В. Листи до рідних / В.Стус // Твори:У 4 т., 6 кн. - Львів: Просвіта, 1997. - Т. 6 (додатковий), кн..1. - 494 с.

Стус 2001 - Стус Д. Василь Стус: Відкрита книга біографії // Василь Стус в контексті європейської літератури: Матеріали II Всеукраїнської наук. конф. // Актуальні проблеми української літератури і фольклору: наук. зб. - Вип.6[відп. ред.. С.В.Мишанич] / Д.Стус. - Донецьк : Вид. Донецького національного університету, 2001. - С.19- 35.

Стаття надійшла 15 грудня 2013 р. 